\title{
Information Literacy through Guided Inquiry: Preparing Students for the $21^{\text {st }}$ Century
}

\author{
Dr. Carol C. Kuhlthau \\ Director of the Center for International Scholarship in School Libraries \\ Rutgers University \\ USA
}

\begin{abstract}
Across the globe, school libraries play an essential role in preparing students for living and working in the $21^{\text {st }}$ century through information literacy. The Rutgers University Center for International Scholarship in School Libraries (CISSL) promotes this initiative in information literacy through research on the impact of school libraries on student learning, research symposia for international scholars, and training institutes for school librarians and teachers. Our research shows that guided inquiry is a dynamic, innovative way of developing information literacy through the school library. Guided inquiry is carefully planned, closely supervised, targeted intervention of an instructional team of school librarians and teachers that leads students through the research process toward independent learning. Guided inquiry develops research skills and subject knowledge as well as fostering cooperative learning, motivation, reading comprehension, language development and social skills that underlie competency for our young people in the $21^{\text {st }}$ century.
\end{abstract}

Educators in countries around the world are debating how best to prepare students for living and working in the $21^{\text {st }}$ century. In many countries, they sense that they are falling behind. The U.S. is particularly concerned with improving competence in math and science as well as in the general level of literacy of low achieving students. Economic leaders and senior policy makers are worried about providing education for developing innovators and creators for the future. Worldwide access to information technology has turned attention to serious questions about education in countries across the globe. How do we educate students to meet the demands for the high levels of literacy of the technological workplace? How do we develop student competence in innovation and creativity for the future of the information society? How do we prepare students for living and working in the $21^{\text {st }}$ century? These questions are at heart of reforming schools to meet the demands of the $21^{\text {st }}$ century. School libraries play an essential role in preparing student for living and working in this dynamic information environment. Are we ready to take up this role? How do we go about doing this?

\section{Center for International Scholarship in School Libraries (CISSL)}

At Rutgers University, Professor Ross Todd and I have established the Center for International Scholarship in School Libraries abbreviated to CISSL but pronounced "sizzle". Our motto is "School libraries spark learning in information age schools." CISSL promotes this initiative through a major program of research on the impact of school libraries on student learning. CISSL provides collaboration and education through research symposia and a virtual research community for international school library scholars and training institutes for school librarians, teachers and administrators. Our research shows that inquiry learning, guided by 
school librarians and teachers, is a dynamic way for developing information literacy and subject knowledge while prompting students' creativity and deep understanding. We call this approach Guided Inquiry.

Information literacy is the ability to access, evaluate and use information. This most simple definition of information literacy captures the essence of what it is to be literate in an information age. These abilities are essential for using a variety of sources of information for life long learning - for living and working in these early decades of the $21^{\text {st }}$ century. How do we prepare our students to be competent at accessing, evaluating and using information? Our research indicates that when students are guided through inquiry learning throughout the elementary and secondary school they gradually build competence in these abilities. The skill and knowledge they develop is fundamental to literacy as they mature in the information age.

\section{Inquiry Learning in $21^{\text {st }}$ Century Schools}

An inquiry approach to learning is being adopted in many schools to address the demands of the $21^{\text {st }}$ century. Inquiry learning raises standard research assignments and school projects to a higher level. Inquiry is way of learning the content of the curriculum rather than simply an extra activity. Inquiry draws on students' life experiences, beginning with things that matter to them and that motivate them to want to know more. Motivation and interest are key elements in inquiry learning. Students use a wide range of sources of information to explore ideas rather than being confined to one textbook of predigested facts. They form their own understandings through conversation and writing throughout the inquiry process. They work with other students to formulate their ideas but are encouraged to create deep understanding for themselves. They gain a sense of ownership and accomplishment in the work they are producing that gradually leads to competence and expertise.

\section{Research on Guiding the Inquiry Process}

My research on the information search process clearly shows that students need guidance and assistance in the inquiry process. Too often students are given a research assignment, shown how to locate some sources of information and then left to their own devices to complete the assignment. This is a missed opportunity to educate students in the kind of abilities they need for the global information society. We need to rethink these assignments to adopt a Guided Inquiry approach that is fundamental to reforming schools for the $21^{\text {st }}$ century.

There are a series of stages in the inquiry process that indicate some critical times when intervention is essential for optimal learning to take place. One of these times is shortly after the initiation of the assignment and the selection of a general topic or question to pursue. At this point most students expect to collect information and to complete the project in a fairly straight forward manner. But their actual experience is quite different.

When I studied feelings of students as well as their thoughts and actions during the stages of the information search process the students' perspective of their experience opened up to me. 
I found two critical stages that are frequently misunderstood and overlooked. These two stages are exploring and formulating after the topic has been selected. This is when the most essential learning takes place. In the Exploration stage students' sense of confusion and uncertainty increases with the conflicting and incompatible information they are encountering. Their information comes from a range of perspectives and formats and frequently does not fit together or match what they already know. Students need to work through these ideas to formulate some theme or point of view. This theme or focus then provides the basis for collecting information and building their learning. During these most difficult stages of the inquiry process students are frequently left on their own and offered little or no guidance. They are rarely given help with strategies to find meaning in the conflicting overwhelming information they are encountering. Most of their instruction concentrates on locating and accessing information and not evaluating and using information for learning. This may have been adequate in the past when research assignments were considered purely academic exercises preparing students for the next phase of their education and sources of information were limited. However, this approach is completely inadequate for preparing students for the information environment of the $21^{\text {st }}$ century. The second edition of my book, Seeking Meaning, Libraries Unlimited, 2004, offers full description of this research and discussion of implications and recommendations for implementation in school libraries and other types of libraries.

In recent studies of inquiry learning in ten schools in New Jersey conducted by CISSL, we found the same pattern of students' feelings with confusion and uncertainty increasing during the exploration stage in the technological information environments of today's school. In fact, advances in information technology have made the exploration and formulation stages more difficult for students to work through on their own and more critical for them to learn to manage. These studies also show that as students move beyond the formulation stage of the inquiry process their interest increases along with their confidence. They become more engaged and interested as they construct their own understanding.

\section{Principles for Guided Inquiry}

Uncertainty is the main concept that underlies the process of learning from a variety of sources of information (Kuhlthau, 2004, 89-105). Uncertainty is the beginning of innovation and creativity. Information initially increases this sense of uncertainty rather than reducing it. Students need to become aware of their own uncertainty and learn to work through ideas that lead to understanding and that decreases uncertainty. Learning begins with uncertainty and is driven by the desire to seek meaning. Once students learn this process it enables them to adapt to a wide range of information-laden tasks in life. As one of my case study subjects explained, "I'll worry about a paper because things don't fall into place but it is not the kind of thing I'll loose sleep over. I've learned to accept that this is the way it works. Tomorrow I'll read this over and some parts will fall into place and some still won't..... The mind doesn't take everything and put it into order automatically and that's it. Understanding that is the biggest help." (Kuhlthau, 2004, 77.

Students need guidance and assistance through out the inquiry process. However, school librarians and teachers can't be there all the time for each and every individual student. In fact to do so would be counterproductive and overbearing for the students. How do we plan when and 
how to intervene in the inquiry process? My research has shown that there are certain times during the inquiry process when students can not move ahead or can move ahead only with great difficulty and these are the times when they are most in need of assistance and most open to instruction. In Seeking Meaning (2004, 127-143), I describe these critical points in the inquiry process as Zones of Intervention. Zones of Intervention, taken from Vygotsky's Zone of Proximal Development, are that area in which a student can do with advice and assistance what he or she cannot do alone or can do only with great difficult. At these times the instructional team of school librarians and teachers has an opportunity to guide the inquiry for engaging, lasting, deep learning.

\section{Transforming Schools for the Information Age}

The configuration of the $21^{\text {st }}$ century information age school is quite different from the $20^{\text {th }}$ century industrial age school. The old model where one teacher and one class of students was the norm in the past. The information age calls for a new model of an instructional team of teachers bringing different expertise to create a collaborative learning environment. For example the school librarian partners with a subject teacher and together they call on the special expertise of other staff members, such as a literacy or reading teacher, technology expert, learning ability specialist, art and music teachers to provide a rich inquiry experience for students working together in pairs and small groups. Intervention is carefully planned by the instructional team to develop research competency and subject knowledge as well as fostering cooperative learning, reading comprehension, language development and social skills.

\section{Guided Inquiry is Planned, Supervised, Targeted Intervention}

Guided inquiry is carefully planned, closely supervised, targeted intervention of an instructional team of school librarians and teachers that gradually leads students through the inquiry process toward independent learning. A new book on Guided Inquiry for school librarians and teachers is scheduled to be published early next year by Greenwood/Libraries Unlimited (Kuhlthau, Maniotes, and Caspari forthcoming). This book emphasizes the application of resources from the community to inquiry learning, particularly museums and experts in the community and resources available electronically on the internet. I am delighted to be writing this book with a museum educator with the Smithsonian in Washington DC and a US National Board literacy specialist with a doctorate degree in curriculum from the University of Colorado (who happen to be my daughters).

We have seen the importance of connecting learning to the student's world. The motivation to learn is sparked by personal interest and relevance in the world outside of school. Through the inquiry process student become engaged in a topic, issue or question that matters to them. They begin to learn how to pursue their own learning in a evolving information environment.

\section{School Librarians Role in Meeting the Challenge of $21^{\text {st }}$ Century Schools}

Guided inquiry is a dynamic innovative way of developing information literacy and for

enhancing the curriculum through the school library. The school library is the information center 
of the $21^{\text {st }}$ century schools providing rich resources for reading and learning within the school and extending the resources of the school through connections with the surrounding community and the wider world. Through guided inquiry students see school learning and real life meshed in integral ways. They develop higher order thinking and strategies for seeking meaning that lead to competencies for creating and innovating. $21^{\text {st }}$ century schools are challenged to develop the human talent in countries around the world. Fully functioning school libraries with qualified school librarians have a significant role in meeting this challenge.

\section{References}

Donham, J., Bishop, K., Kuhlthau. C.C., \& Oberg.D. (2001). Inquiry Based Learning: Lessons from Library Power. Worthington, Ohio: Linworth Publishing.

Harada, V. and Yoshina, J. (2004). Inquiry Learning through Librarian-Teacher Partnerships. Worthington, Ohio: Linworth Publishing.

Kuhlthau, C. C. (2004). Seeking Meaning. $2^{\text {nd }}$ edition, Westport, Connecticut: Libraries Unlimited.

Kuhlthau, C. C., Maniotes, L., \& Caspari, A. (forthcoming). Guided Inquiry. Westport, Connecticut: Libraries Unlimited.

\section{Author Note:}

Carol Collier Kuhlthau, Professor Emerita of Library and Information Science, Rutgers University USA and Director of the Center for International Scholarship in School Libraries, is internationally recognized for her research on learning through the information search process (ISP). She has received many awards including the American Library Association Shera Award for Outstanding Research, the Library and Information Technology Association Kilgour Award for Research, the American Society for Information Science and Technology Research Award, the America Association for School Librarians Distinguished Service Award, The Association for Library and Information Science Education Professional Contribution Award, and the Association of College and Research Libraries Dudley Instruction Award. Her many publications include Seeking Meaning: a Process Approach to Library and Information Services $2^{\text {nd }}$ edition in 2004 and Guided Inquiry, a new book for school librarians and teachers, forthcoming in 2007 both published by Greenwood/Libraries Unlimited. 
Reproduced with permission of the copyright owner. Further reproduction prohibited without permission. 